\title{
Integrating Decision Tools for the Sustainable Management of Land Contamination
}

\author{
S.J.T. Pollard ${ }^{\mathrm{a} *}$, A. Brookes ${ }^{\mathrm{b}}$, N. Earl ${ }^{\mathrm{c}}$, J. Lowe $^{\mathrm{d}}$, T. Kearney $^{\mathrm{e}}$ and C. P. Nathanail ${ }^{\mathrm{f}}$
}

${ }^{a}$ Integrated Waste Management Centre, School of Industrial \& Manufacturing Science, Building 61, Cranfield University, Bedfordshire, MK43 0AL, UK

${ }^{\mathrm{b}}$ Gifford Consulting Engineers, Carlton House, Ringwood Road, Woodlands, Southampton, Hampshire SO40 7HT, UK

${ }^{\mathrm{c}}$ Atkins Environment, The Axis, 10 Holliday Street, Birmingham, B1 1TF, UK

${ }^{\mathrm{d}}$ Independent Consultant, 160 Trafalgar Street, London, SE17 2TP, UK

${ }^{\mathrm{e}}$ Environment Agency, Olton Court, 10 Warwick Road, Olton, Solihull, B92, 7HX, UK

${ }^{\mathrm{f}}$ Land Quality Management, SChEME, The University of Nottingham, Nottingham NG7 2RD, UK

\begin{abstract}
Abtract
The approach to taking decisions on the management of land contamination has changed markedly over 30 years. We have moved from a cost-centred approach in the mid-1970s, through the technologies of the mid-1980s, on to the risk-based approaches of the mid-1990s and into a new millennium where environmental decisions must be "socially-robust" and sustainable. It has been a rollercoaster ride with policy makers and regulators, practitioners and researchers having to keep pace with new technologies, assessment criteria and diagnostic methods for their measurement, techniques for risk analysis and the frameworks that support decision-makers in their efforts to regenerate historically contaminated land. Having worked our way from simple hazard assessment through to the need for "sustainability appraisal" we might now consider piecing together the experience of decision-making for managing land contamination. Here, we reflect critically on recent developments with a view to considering how better decisions can be made by integrating the decision tools available.

Keywords: land contamination, decision-making, sustainable development, risk-based land management

* corresponding author: Tel: +44(0)1234 754 101; Fax: +44(0)1234 751 671; email: s.pollard@ cranfield.ac.uk
\end{abstract}




\section{Introduction}

The approach to taking decisions on the management of contaminated sites has changed markedly over 30 years. We have moved from a cost-centred approach in the mid-1970s, through the technology feasibility studies of the mid-1980s, the risk-based approaches of the mid-1990s and into a new millennium where environmental decisions must be "sociallyrobust" within a context of sustainable development (Urban Task Force, 1999; ESRC Global Environmental Change Programme, 2000). These decades represent our efforts to ensure regeneration is affordable, feasible, effective and latterly, sustainable. Now, and as a result of our acquired understanding, successful management of land contamination whether at the site, regional or national scale relies on applying a large and multidisciplinary knowledge base that straddles the natural, physical, engineering and social sciences within a practical, commercial, regulatory and often community context (Pollard et al., 2001a).

Decision-makers must not only be able to synthesise and apply this knowledge but also work in a modern decision-making environment with an emphasis on 'process', wider participation and deliberation. A decade ago, Renn (1992) voiced the need for "a (decision) process that facilitates the involvement of all affected parties and at the same time produces a prudent and informed judgement based on expertise and knowledge" as one of the major challenges of a modern democratic society. The success of such a process, whether for decisions on land contamination or other environmental pressures, depends on time, openness, the equal position of all parties and a willingness to learn. Socially robust decisions make the presumption of access to resources, flexibility in the decision-making process and an inherent capacity and desire for change (Homan et al., 2001; Brookes et al., 2001).

The new expectations of stakeholders including the public are there to see. There is growing public interest in, and engagement with, the process of decision-making, an 
increasing expectation of access to the technical documents and judgements of technical experts that support decisions on risk, and increased public scrutiny of the risk work of companies, their professional advisors and of the regulators (House of Lords Select

Committee on Science and Technology, 2000; Green Alliance, 2000). Stakeholders and publics wish to understand and influence decision-making processes and their outcomes (Fischer, 1993; ESRC Global Environmental Change Programme, 2000). The response required of decision-makers is to make judgements transparent, explicit and open for challenge and to be clear about where those opportunities exist in the decision-making process (ILGRA, 1998; Petts, 2000).

\section{Making decisions about land contamination}

Decision-makers managing land contamination in the new millennium face complex issues of financial liability, securing development funding, the management of a series of regulatory interfaces, of interpreting sophisticated analytical data and risk assessments, the relative capabilities of remediation technologies and the maintenance of public confidence in remediation projects - all of which impact on the decision process and outcome (Vegter et al., 2002; Pollard and Earl, 2003). Other than for large-scale regeneration projects that progress over 5-10 years, the application of integrated frameworks that consider environmental, social and economic factors (Stern and Fineberg, 1996; Presidential / Congressional Commission, 1997; van der Vorst et al., 1999) may be hard to justify. Most projects require fast turnaround, development-led decisions, often with little capacity for the revisiting of data and tiered approaches to chemical analysis and risk assessment. Short timescales force a linear approach to taking decisions and there is pressure to reach decisions quickly. Acknowledging the practical and developing needs of risk management, governments, research organisations and industry bodies have developed practical guidance for decision-makers on negotiating the 
maze of factors influencing land contamination decisions (CONCAWE, 1997; ASTM, 1995;

2001; Environment Agency, 2003). But how, having acknowledged the complexity of the decision making context, do we apply integrated decision-making in practice? Here we explore some of the decision tools available beyond the well-referenced technique of risk assessment and, in the context of land contamination, explore the practical challenges for integrating these tools within the decision frameworks that are beginning to emerge.

\section{Sustainable Development, Decision-Making and Land Contamination}

The UK strategy for sustainable development (Cm 4345, 1999), which has as its aim establishing a better quality of life for present and future generations, has the key objectives of (i) social progress which recognises the need of everyone (equity within and between generations); (ii) effective protection of the environment (proactive approach to limiting environmental damage); (iii) prudent use of natural resources (clean and efficient use of nonrenewable and renewable resources); and (iv) maintenance of high and stable levels of economic growth and employment (improved living standards for all; quality goods and services; education and skills). Application of the sustainable development agenda to soil quality (Puri and Gordon, 1998; DETR 2000; Defra, 2001) is focussing on historic land contamination and the wider aspects of soil quality, including (progressing from from aim, through application to evaluation): (i) bringing land back into early beneficial use; (ii) reducing pressure on greenfield sites and the pollution of groundwater, thus conserving agricultural land and natural habitats; (iii) adoption of a suitable-for-use approach towards land remediation; (iv) the efficient use of national resources to tackle issues of highest risk at priority sites; (v) prioritising remedial action so as to address the worst risks first in relation to the use of the land concerned; (vi) the application of sustainable remediation technologies that conserve land and resources; (vii) development and maintenance of new partnerships and 
fora among key stakeholders with agreements on a common research and practice agenda; (viii) the consideration of point and diffuse sources of soil pollution over the long term; (ix) the development of monitoring systems that allow early detection of adverse soil, water and ecosystems changes; and $(\mathrm{x})$ the distribution of impacts from land contamination on communities. In the UK, these issues are being addressed through a combination of policy, regulatory, voluntary and technological responses, supported in turn by the application of decision tools at the strategic and operational level.

Environmental regulators and land-use planners have at their disposal a considerable array of tools (Table 1) to assist with screening environmental impacts, assessing risk / benefit trade-offs, engaging wider stakeholder communities within decision-making and the integration of technical, socio-political and economic factors that inform environmental decisions (e.g DETR, 1998; RCEP, 1998; Sexton et al., 1999; USEPA, 1999, Alker et al., 2000). These tools are not only used increasingly at the strategic (policy and programme) and operational (plan and project) levels (Figure 1) but across a wide spectrum of environmental issues (DETR, 1998; Nijboer, 1998; USEPA, 1999; Brookes et al., 2001). At the heart of the technical assessment, practitioners have developed frameworks making use of the wellestablished processes of risk assessment, management and communication (Ferguson et al., 1998). However, many of these processes have developed rather in isolation of each other and often without a clear reference to the decision being taken.

Current approaches to the management of risks from land contamination have much in common with many modern environmental decisions that demand an holistic approach. Increasingly, national and international reports (USEPA, 2001; Vegter, 2002; Environment Agency, 2003) encourage practitioners to connect these aspects of decision-making within an overarching philosophy of risk-based land management (RBLM) and adopt a broader range of 
Pollard and Earl, 2003; Table 1) including:

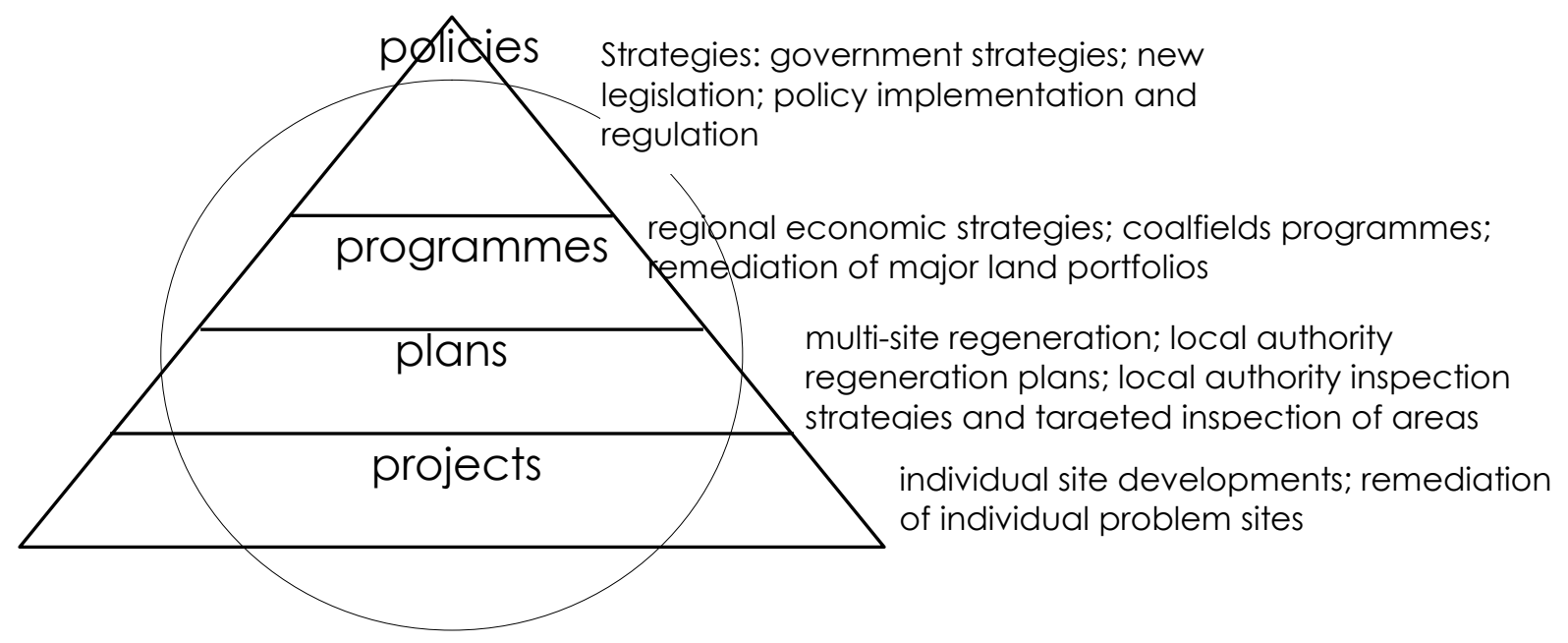

Social, economic, environmental, natural resource factors conceptual model development);

- statistical data analysis (e.g. in geotechnical and geoenvironmental site investigation); environmental fate and transport modelling (as a component of exposure assessment);

- scoping, screening and prioritisation techniques (in qualitative risk assessment; in remedial technology selection);

- sensitivity and uncertainty analysis (in quantitative risk assessment);

- public consultation workshops;

- economic appraisal of costs and benefit (in comparing remedial approaches, including the costs of 'do nothing' and the assessment of appropriate times for intervention); and

- the collection of opinions and lay-perspectives on risk (for risk communication and decision making).

- brainstorming techniques (e.g. for project risk assessment, hazard identification and

Fig. 1 Decision-making at different scales: from policy to project level assessment with examples of various contexts for land contamination. 
1 This challenge to practitioners to widen their perspective and embrace increasingly formal and integrated tools comes at a time where achieving the balance of economic, social and environmental benefits of dealing with land contamination is increasingly critical at all levels of delivery. Money is in short supply, societal pressures, particularly in relation to land use and development density, are increasing and predictions about the long term quality of human health and the environment are if anything, increasingly uncertain.

Decisions about different aspects taken in isolation are no longer sufficient. The regeneration of brownfield land offers a good example of the need for robust and integrated decision making. The drivers for regeneration have traditionally been economic, leading to a demand for simplified assessment of risk with minimum costs of requirements to deal with risks. At a political level, the new drivers are often social, but this can equally lead to biased views about the benefits of remediation in relation to the use of the land, or a narrow targeting of remediation on particular areas where there is immediate demand for new uses of land. At a wider level however, there is a need to provide a higher overall quality of life, sustainable water resource management and biodiversity, without simply transferring the problem to another environmental medium, geographical location or generation. This means that long term health and environmental risk assessment have to be at the heart of regeneration decisions, rather than simply one of the processes that takes place to deliver prejudged outcomes. 
1 Table 1: Broad typology of decision tools for environmental decision-makers with application to land contamination (after Pollard et al., 2001b)

\begin{tabular}{|c|c|c|c|}
\hline Tool & Use & $\begin{array}{l}\text { Environmental arena in which tool has been } \\
\text { conventionally applied }\end{array}$ & Land contamination decision context \\
\hline $\begin{array}{l}\text { Environmental } \\
\text { risk assessment }\end{array}$ & $\begin{array}{l}\text { Estimation of probability and } \\
\text { consequence, usually for adverse } \\
\text { environmental impacts at the site- } \\
\text { specific level, but can be applied at } \\
\text { policy level as strategic risk } \\
\text { assessment (SRA). }\end{array}$ & $\begin{array}{l}\text { Chemical product licensing, manufacture and } \\
\text { use; production plant safety; environmental } \\
\text { health protection; environmental planning and } \\
\text { environmental permitting; flood defence; liability } \\
\text { auditing; contaminated land assessment; policy } \\
\text { analysis; strategy setting. }\end{array}$ & $\begin{array}{l}\text { Context well established; identification and } \\
\text { analysis of hazards and potential environmental } \\
\text { harm from contaminated sites; use of } \\
\text { probabilistic techniques for dealing with } \\
\text { uncertainties in exposure assessment; sensitivity } \\
\text { analysis to assist in remedial technology } \\
\text { selection; increasing focus on dose-response } \\
\text { assessment and ecological risk assessments. }\end{array}$ \\
\hline $\begin{array}{l}\text { Environmental } \\
\text { (impact) } \\
\text { assessment }\end{array}$ & $\begin{array}{l}\text { Environmental, impacts of proposed } \\
\text { developments; summarised in non- } \\
\text { technical language; participatory } \\
\text { approach advocated; can also be } \\
\text { applied at the policy or sectoral level } \\
\text { as strategic environmental assessment } \\
\text { (SEA). }\end{array}$ & $\begin{array}{l}\text { Environmental development planning; siting of } \\
\text { contentious installations (e.g. incinerators, } \\
\text { landfills, tidal barrage); policy analysis; business } \\
\text { sector analysis. May be supplemented by } \\
\text { environmental risk assessment where health } \\
\text { effects are of concern. }\end{array}$ & $\begin{array}{l}\text { Siting of plant for the long-term treatment of } \\
\text { residuals (e.g. secondary treatment of pumped } \\
\text { groundwater); siting of containment facilities: } \\
\text { scoping matrix approach for principal } \\
\text { environment impacts. Strategic environmental } \\
\text { assessment may extend to land regeneration } \\
\text { programmes and strategies. }\end{array}$ \\
\hline $\begin{array}{l}\text { Social impact } \\
\text { assessment }\end{array}$ & $\begin{array}{l}\text { Assessment of the impacts of planned } \\
\text { developments on the social fabric of } \\
\text { communities, includes equity issues } \\
\text { and impacts on social processes. }\end{array}$ & $\begin{array}{l}\text { Not as yet conventionally applied in UK, more } \\
\text { focused in USA and developing countries, but } \\
\text { might provide useful basis for assessing the } \\
\text { "social" part of sustainable development. }\end{array}$ & $\begin{array}{l}\text { Not in explicit current use. On more complex } \\
\text { sites, SIA could be used to analyse the social } \\
\text { context of a site or regeneration programme and } \\
\text { to identify key pressures and benefits / possible } \\
\text { constraints on remediation }\end{array}$ \\
\hline $\begin{array}{l}\text { Health Impact } \\
\text { Assessment }\end{array}$ & $\begin{array}{l}\text { Assessment of the health impacts of a } \\
\text { development or process. Akin to EIA } \\
\text { with broader emphasis on health (not } \\
\text { just toxicological) impacts of } \\
\text { developments. }\end{array}$ & $\begin{array}{l}\text { Recent call for it to be integrated into EIA - little } \\
\text { distinction in practice from human health risk } \\
\text { assessment within a planning context. } \\
\text { Application in the context of air quality impact } \\
\text { assessments for siting incinerators. }\end{array}$ & $\begin{array}{l}\text { Nested within human health risk assessment. } \\
\text { Broader health impacts (e.g. psychological } \\
\text { impacts, anxiety etc.) recognised though not } \\
\text { formally assessed. }\end{array}$ \\
\hline
\end{tabular}


1 Table 1 cont'd: Broad typology of decision tools for environmental decision-makers with application to land contamination (after Pollard et al., 2001b)

\begin{tabular}{|c|c|c|c|}
\hline Tool & Use & $\begin{array}{l}\text { Environmental arena in which tool has been } \\
\text { conventionally applied }\end{array}$ & Land contamination decision context \\
\hline $\begin{array}{l}\text { Cost-benefit } \\
\text { analysis }\end{array}$ & $\begin{array}{l}\text { Systematic and consistent appraisal } \\
\text { and evaluation of economic and } \\
\text { environmental costs and benefits of } \\
\text { alternative projects, strategies and } \\
\text { policies. }\end{array}$ & $\begin{array}{l}\text { Appraisal of proposed investments in flood } \\
\text { defence projects; BATNEEC and BPEO } \\
\text { assessments of pollution control measures; policy } \\
\text { appraisal and regulatory impact assessments. }\end{array}$ & $\begin{array}{l}\text { Not routinely used in UK. Comparative } \\
\text { assessment of risk reduction and costs for a } \\
\text { variety of remedial technologies; assessing } \\
\text { intervention times for groundwater plume } \\
\text { remediation; at the strategic level may contribute } \\
\text { to policy appraisal of statutory instruments and } \\
\text { regulatory policies for contaminated sites. } \\
\text { Formal cost-benefit tools being applied } \\
\text { especially for optimising remediation of soils and } \\
\text { water. }\end{array}$ \\
\hline $\begin{array}{l}\text { Multi-criteria } \\
\text { analysis (MCA) } \\
\text { and multi-attribute } \\
\text { techniques (MAT) }\end{array}$ & $\begin{array}{l}\text { Integrated assessment of technical, } \\
\text { social and economic impacts of } \\
\text { alternative projects, strategies and } \\
\text { policies. This incorporates } \\
\text { monetisable/ quantifiable and non- } \\
\text { monetisable/quantifiable impacts. }\end{array}$ & $\begin{array}{l}\text { Assessment of risk management options; } \\
\text { consistent appraisal of environmental benefits of } \\
\text { water quality improvements by water industry so } \\
\text { as to prioritise these measures in terms of their } \\
\text { cost-effectiveness of securing environmental } \\
\text { benefits. }\end{array}$ & $\begin{array}{l}\text { Assessment of technical, socio-political and } \\
\text { economic factors associated with a range of } \\
\text { remedial options; integrating 'soft' data on risk } \\
\text { perception and political risk with quantitative } \\
\text { cost estimates and remediation efficiencies. } \\
\text { Initial decision tools produced in the } \\
\text { Netherlands. These allow for greater stakeholder } \\
\text { discussion over broader benefits of remediation. }\end{array}$ \\
\hline $\begin{array}{l}\text { Environmental } \\
\text { audit }\end{array}$ & $\begin{array}{l}\text { Account of activities and production } \\
\text { and resulting effects on environment; } \\
\text { usually undertaken by an independent } \\
\text { team with management support; the } \\
\text { collation, analysis, interpretation and } \\
\text { documentation of practices relevant to } \\
\text { environmental requirements; checklist } \\
\text { and Y/N guide approaches are } \\
\text { common. }\end{array}$ & $\begin{array}{l}\text { Improvement plans; setting insurance premiums; } \\
\text { corporate environmental accounting and } \\
\text { statements; liability (mergers, acquisitions and } \\
\text { divestitures); regulatory compliance; efficiency } \\
\text { of environmental management systems (EMS); } \\
\text { due diligence; waste minimisation. }\end{array}$ & $\begin{array}{l}\text { Well established for multi-site comparisons and } \\
\text { merger and acquisition assessments; focus is on } \\
\text { qualitative risk assessment: source-pathway- } \\
\text { receptor approach, worst-case and 'reasonable' } \\
\text { worst-case scenarios to drive remedial cost } \\
\text { (liability) estimates. Considerable uncertainty in } \\
\text { absence of site-specific information; multi-site } \\
\text { comparisons undertaken by reference to source, } \\
\text { receptor characteristics and regulatory pressure. }\end{array}$ \\
\hline Life cycle analysis & $\begin{array}{l}\text { Energy and mass balance from cradle } \\
\text { to grave of products. }\end{array}$ & $\begin{array}{l}\text { Manufacture; product replacement and } \\
\text { substitution; supply and product chain } \\
\text { management. }\end{array}$ & $\begin{array}{l}\text { The design of sustainable remediation } \\
\text { technologies and programmes; extension beyond } \\
\text { simple CAPEX and OPEX expenditure to issues } \\
\text { of energy / resource consumption and the } \\
\text { secondary issues of treatment residuals } \\
\text { management. }\end{array}$ \\
\hline
\end{tabular}


1 Table 1 cont'd: Broad typology of decision tools for environmental decision-makers with application to land contamination (after Pollard et al., 2001b)

\begin{tabular}{|c|c|c|c|}
\hline Tool & Use & $\begin{array}{l}\text { Environmental arena in which tool has been } \\
\text { conventionally applied }\end{array}$ & Land contamination decision context \\
\hline $\begin{array}{l}\text { Sustainability } \\
\text { appraisal }\end{array}$ & $\begin{array}{l}\text { Developing area. Appraisal } \\
\text { framework using sustainability } \\
\text { objectives; potential application at all } \\
\text { levels; flexible iterative process; } \\
\text { indicators to monitor process; } \\
\text { matrix/checklist approach. }\end{array}$ & $\begin{array}{l}\text { Appraisal of regional planning guidance and } \\
\text { regional strategies; policy and strategy level } \\
\text { appraisal. Relatively recent developments. }\end{array}$ & $\begin{array}{l}\text { Potential application to the appraisal of national } \\
\text { or regional or site scale land regeneration } \\
\text { programmes. Best viewed in terms of the } \\
\text { integration of the above techniques. }\end{array}$ \\
\hline $\begin{array}{l}\text { Stakeholder } \\
\text { analysis }\end{array}$ & $\begin{array}{l}\text { Approach to analyzing the } \\
\text { stakeholders involved in the decision } \\
\text { process. Informal to formal } \\
\text { approaches available; enables } \\
\text { systematic consideration of all relevant } \\
\text { parties and the relationships between } \\
\text { those parties. Can provide an audit } \\
\text { trail. }\end{array}$ & $\begin{array}{l}\text { Carried out in an informal way within the EIA } \\
\text { process. Associated more with social impact } \\
\text { assessment advocated by stakeholder dialogue } \\
\text { practitioners as a component of other decision- } \\
\text { making processes. }\end{array}$ & $\begin{array}{l}\text { Enables a systematic approach to understanding } \\
\text { the range of stakeholders involved with a site / } \\
\text { regeneration programme. Potential application to } \\
\text { understanding the potential range of opinions and } \\
\text { values that might be expressed regarding specific } \\
\text { remediation options. }\end{array}$ \\
\hline $\begin{array}{l}\text { Engagement } \\
\text { techniques }\end{array}$ & $\begin{array}{l}\text { Citizen's juries - Involves major } \\
\text { stakeholders in the process of the } \\
\text { identifying and appraising of options - } \\
\text { lay people brought together to } \\
\text { deliberate on an issue, call witnesses } \\
\text { and come to a verdict. Citizen's } \\
\text { advisory groups - lay people brought } \\
\text { together over a period of weeks to act } \\
\text { as the voice of the community - can } \\
\text { turn into a monitoring group once the } \\
\text { decision has been made. }\end{array}$ & $\begin{array}{l}\text { Applied in the context of hazardous and } \\
\text { radioactive waste management. }\end{array}$ & $\begin{array}{l}\text { Potential application for complex contentious } \\
\text { sites where a number of remediation options are } \\
\text { possible and an informed public debate is } \\
\text { desirable. Increasing interest in participatory } \\
\text { decision-making for contaminated land rather } \\
\text { than risk communication as a 'bolt-on' on project } \\
\text { completion. }\end{array}$ \\
\hline
\end{tabular}




\section{Risk and economic appraisal: an example of integration}

One component of the appraisal of sustainable remediation, economic appraisal, brings new considerations to the decision-making process (Martin et al., 1998; Environment Agency, 2000a) such as issues of market failure, "opportunity costs", the law of diminishing returns and the "valuation of impacts". The purpose of an economic appraisal is not only to estimate the level of the costs and benefits of the options for risk management, but also to identify the key factors determining them so as to seek out and refine better options for all concerned with lower costs and greater environmental and social benefits. Economic appraisal relies on the findings of the risk assessment.

For regulatory authorities considering the remediation of orphan sites, an appraisal might typically involve determining whether statutory requirements or other remediation aims or objectives set by an overarching authority exist, for example, by the Department for Environment, Food and Rural Affairs (Defra), the Office of the Deputy Prime Minister (ODPM) or the European Commission (EC). Statutory requirements may stipulate some qualitative caveats regarding the stringency with which agencies should apply them such as 'unless excessively costly' or 'unless there are overriding public interests'. In such cases the analysis would have to consider how these qualitative caveats are translated into the decision process. For example, under Part IIA of the Environmental Protection Act 1990 in England and Wales (DETR, 2000), the main aim for remediation is to ensure that a significant pollutant linkage no longer exists, to the extent that this can be achieved using the best combination of practicability, effectiveness and durability that is reasonable with regard to the balance of costs and benefits and by reference to the seriousness of the risk.

Taking into account any pre-set remediation objectives and other regulatory or policy constraints, the full range of objectives that are theoretically possible, and at least practically feasible, should be identified. This should consider alternatives for the timing of remediation. 
For example, in land restoration programmes, remediation may have as its aims not only the removal of a significant pollutant linkage in relation to Part IIA (DETR, 2000), but also in the long term the return of the land to a different beneficial use.

It is then necessary to integrate the economic impacts with the environmental, economic and social impacts of the different remediation objectives to determine the most appropriate aim of remediation of the site. The appraisal should include the costs of the options and their environmental impacts (both positive and negative) and consider impacts assessed in monetary terms (e.g. impacts on local properties) and intangible impacts (e.g. on human health and ecosystems). In situations where more than one option is necessary, it may be cost-effective and practicable to consider the integration of the options into an overall strategy. The appraisal should set out as fully as possible the level, nature and significance of these impacts building on scientific assessments of the overall reduction in the environmental impact that the remediation provides. Such assessments might be encouraged to include the social benefits of remediation such as increased amenity value.

Finally, the law of diminishing returns reflects the reality that the trade offs between reducing environmental damage and the costs of this reduction become more significant as remediation progresses (Earl and Kearney, 2000; Environment Agency, 2000b). This has significant implications for the economic appraisal of remediation options.

\section{Integration in Practice}

Accounting for a multitude of decision factors generates considerable challenges for decisionmakers including the effectiveness, practicability and cost of implementing integrated approaches and the inevitable issues of terminology (Table 2).

With respect the effectiveness of integrated decisions, one might ask whether structured approaches to decision-making provide for greater decision-making power and 
better decisions. Pragmatists often argue that the incremental costs associated with the environmental appraisal of remediation projects are rarely justified when viewed in terms of the final outcome, which may have been arrived at through professional judgement without recourse to a particularly structured analysis. However, structured analysis, which does not need to override professional judgement, does improve consistency and offer a transparency of approach, providing the aims and boundaries of the assessment (risk assessment, options appraisal) are clearly set out. A further response is to view not only the cost-effectiveness but also the uptake of a decision by stakeholders (including the risk takers) as a critical indicator of success (Brookes et al., 2001).

Practicability is important if the credibility of decision tools is to be upheld. Option appraisal tools should be integral to the decision-making process and practised iteratively. Application of these tools need not be onerous (Brookes et al., 2001). Many appraisals can be completed using inexpensive, but transparent screening techniques (rapid appraisal) with more sophisticated tools (technical appraisal) being reserved for contentious, complex, or higher priority projects. Screening is an accepted methodology in environmental impact assessment and is becoming recognised (in the UK) as a means of targeting resources at the most deserving issues at more strategic levels. Checklist approaches, although with recognised limitations, have been used widely. The approach is analogous to the Government's tiered approach to environmental risk management (DETR et al., 2000; Defra, 2002; Figure 2) and has been adopted for land affected by contamination in the Environment Agency's model procedures for the management of land contamination (Environment Agency, 2003). Many appraisals have core (fixed) and non-core (variable) aspects to their analysis and decision-makers can streamline their appraisal efforts accordingly by identifying core issues at a screening stage and focusing any additional effort on decision-critical aspects of the analysis. 
1 Table 2: Integrating decision-support tools: some key challenges

\begin{tabular}{|c|c|c|}
\hline Challenge & General commentary & Land contamination decision context \\
\hline $\begin{array}{l}\text { Identifying the full } \\
\text { aspects of a problem }\end{array}$ & $\begin{array}{l}\text { Time needs to be invested at the outset to determine all these } \\
\text { aspects. For example, there may be a mix of traditional EIA issues, } \\
\text { risk and potential social and economic impacts. Application of } \\
\text { brainstorming and 'risk register' techniques may help. Wide } \\
\text { consideration of stakeholder views needed. Key practical challenge } \\
\text { is of how to include all diverse impacts, aspects and considerations } \\
\text { of a problem in a systematic manner without 'double-counting'. }\end{array}$ & $\begin{array}{l}\text { Emphasis is usually on scoping out technical detail and conceptual } \\
\text { model development, but often less emphasis on economic and } \\
\text { social aspects of remedial programmes at the outset. Less the case } \\
\text { for land regeneration subject to strategic assessment under the } \\
\text { auspices of, for example, a local or regional plan. Need for site } \\
\text { work to be risk-led and risk-based when dealing with historic land } \\
\text { contamination. }\end{array}$ \\
\hline $\begin{array}{l}\text { Setting boundaries } \\
\text { for the analysis }\end{array}$ & $\begin{array}{l}\text { These need to be established and agreed both for consistency and } \\
\text { for transparency and to make the appraisal practical. For example, } \\
\text { there is a growing interest in EIA approaches encapsulating the } \\
\text { entire life cycle of a project, ranging from the winning of raw } \\
\text { materials to the final decommissioning and disposal stages. But } \\
\text { there is a danger of becoming overwhelmed in excessive and } \\
\text { unnecessary detail, so the analysis should concentrate on issues of } \\
\text { significance to the environmental, economic and social impacts. }\end{array}$ & $\begin{array}{l}\text { Tend to be established by regulatory context and owner / } \\
\text { developer. Often technically, or financially driven with less } \\
\text { emphasis on social issues. Greater consideration and involvement } \\
\text { of the range of audiences earlier on may help avoid difficulties } \\
\text { later with respect to disagreements over the scope of studies, the } \\
\text { communication of risk assessment output and remedial technology } \\
\text { selection, though not a guarantee against disagreement. }\end{array}$ \\
\hline $\begin{array}{l}\text { Selecting individual } \\
\text { techniques to } \\
\text { potentially solve a } \\
\text { problem }\end{array}$ & $\begin{array}{l}\text { It is difficult to find off-the-peg techniques that are scientifically, } \\
\text { professionally and socially acceptable. There is a dearth of } \\
\text { guidance. At present a wide range of methods exist from formal } \\
\text { frameworks such as Risk Assessment, EIA and CBA to deliberative } \\
\text { approaches. Any single problem may require unique or novel } \\
\text { approaches tailored to the case in question, or adaptation of an } \\
\text { existing decision-making tool. This can take time in the short run, } \\
\text { but can avoid significant problems at a later stage. }\end{array}$ & $\begin{array}{l}\text { Most decision tools require tailoring to the specific circumstances } \\
\text { of the site because the context of application often requires an } \\
\text { emphasis on certain aspects. An obvious example is the emphasis } \\
\text { put on exposure assessment within the application of risk } \\
\text { assessment for land contamination. This may require adjustment } \\
\text { to site-specific circumstances with the input of local knowledge } \\
\text { and data on exposure scenarios. }\end{array}$ \\
\hline $\begin{array}{l}\text { Maintaining } \\
\text { professional rigour } \\
\text { whilst working in a } \\
\text { multidiscipline } \\
\text { fashion to integrate } \\
\text { techniques }\end{array}$ & $\begin{array}{l}\text { It is essential to apply rigorous professional standards in each } \\
\text { discipline's contribution, while still enabling their combination for } \\
\text { the development of integrated techniques. }\end{array}$ & $\begin{array}{l}\text { Clear specification of the impacts of remediation option across } \\
\text { disciplines (technical, economic, social), without double counting, } \\
\text { during appraisal. Recognition of the need for multidiscipline } \\
\text { teams and recognition of limitations regarding the boundaries of } \\
\text { professional knowledge (engineering; analytical chemistry etc.) }\end{array}$ \\
\hline
\end{tabular}


1 Table 2 cont' $\mathbf{d}$ : Integrating decision-support tools: some key challenges

\begin{tabular}{|c|c|c|}
\hline Challenge & General commentary & Land contamination decision context \\
\hline $\begin{array}{l}\text { Linking tools and } \\
\text { techniques together } \\
\text { as appropriate }\end{array}$ & $\begin{array}{l}\text { This is difficult because of the specific boundaries that surround } \\
\text { techniques and the form in which each technique produces its } \\
\text { findings. For example, risk assessment may report on the } \\
\text { significance of a contaminant exceeding a threshold, whereas } \\
\text { options appraisal techniques also need an analysis of risk reduction } \\
\text { and residual risk to allow decisions to be made. Often it will be } \\
\text { necessary to combine qualitative and quantitative information. } \\
\text { Furthermore, models on which techniques are based may be } \\
\text { incompatible. }\end{array}$ & $\begin{array}{l}\text { Clearest example is of using risk assessment output to inform } \\
\text { remedial objectives. These processes still often viewed as } \\
\text { distinct, however. There is a greater need to practice early } \\
\text { iteration of risk management decisions following screening level } \\
\text { risk assessments, so as to refine detailed risk assessment work. }\end{array}$ \\
\hline $\begin{array}{l}\text { Appropriate } \\
\text { terminology to avoid } \\
\text { misinterpretation of } \\
\text { key terms and jargon }\end{array}$ & $\begin{array}{l}\text { The above challenges are compounded by differences in the } \\
\text { language and jargon customarily used by different disciplines and } \\
\text { the interpretations attached to specific terms. Differences in } \\
\text { understanding between and within disciplines, between stakeholders } \\
\text { need to be addressed early on. }\end{array}$ & $\begin{array}{l}\text { A common problem across the field of risk. Terminological } \\
\text { differences can be overcome by focusing attention on the } \\
\text { fundamental questions for which answers are sought. For } \\
\text { example: hazard identification - what hazards are present on site? } \\
\text { How might the consequences be realised? Who or what is at risk } \\
\text { from these consequences? etc. }\end{array}$ \\
\hline Non-dominance & $\begin{array}{l}\text { No single technique or discipline must dominate the others or be } \\
\text { perceived as dominating in reaching a final decision. }\end{array}$ & $\begin{array}{l}\text { Historically, cost has dictated remedial selection. Structured, } \\
\text { integrated analysis may result in challenges to the way that this is } \\
\text { presented. Multidiscipline approach means a range of factors are } \\
\text { seen as valid, though not necessarily to an equal degree. }\end{array}$ \\
\hline $\begin{array}{l}\text { Consideration of } \\
\text { increased public } \\
\text { involvement }\end{array}$ & $\begin{array}{l}\text { Current calls for increased public participation. There is } \\
\text { considerable experience in EIA but less so in risk assessment, CBA } \\
\text { or technology assessment. Structured and focused approaches are } \\
\text { necessary, together with an examination of institutional structures } \\
\text { and their capacity for meaningful public involvement. Monitoring } \\
\text { and validation of these mechanisms is critical. }\end{array}$ & $\begin{array}{l}\text { Increasing interest in risk assessment design and output. } \\
\text { Approach to date has been on technical risk assessment followed } \\
\text { by 'risk communication' exercises to discuss output. US } \\
\text { experience suggests limited success in this regard and many } \\
\text { commentators now point to a need to apply engagement and } \\
\text { participatory approaches. UK experience suggests the earlier this } \\
\text { is done the better. }\end{array}$ \\
\hline Considering values & $\begin{array}{l}\text { Deliberation is one way of uncovering people's values, but there are } \\
\text { challenges as to how those values are incorporated into decision- } \\
\text { making and how representative groups are, such that deliberative } \\
\text { analysis of small groups views may need to be supplemented by } \\
\text { surveys of a larger sample of the relevant population. }\end{array}$ & $\begin{array}{l}\text { Likely to have a complex range of values associated with a } \\
\text { contaminated site. Potential for inadvertent scientific and } \\
\text { professional bias in risk assessments; consideration of broader } \\
\text { stakeholder values with respect to remedial objectives. Early } \\
\text { discussion of varied agendas is important. }\end{array}$ \\
\hline $\begin{array}{l}\text { Risk perceptions and } \\
\text { lay epidemiology }\end{array}$ & $\begin{array}{l}\text { Understanding the perspectives from which lay people address } \\
\text { problems and valuing their local knowledge - challenge as to how } \\
\text { local knowledge sits alongside expert knowledge. }\end{array}$ & $\begin{array}{l}\text { Local effects attributed to sites by individuals / communities. } \\
\text { Difficulties of establishing causality and reconciling reported } \\
\text { observations alongside exposure assessments. }\end{array}$ \\
\hline
\end{tabular}


1 Table 2 cont'd: Integrating decision-support tools: some key challenges

\begin{tabular}{|c|c|c|}
\hline Challenge & General commentary & Land contamination decision context \\
\hline Handling uncertainty & $\begin{array}{l}\text { Recognition that in addition to uncertainty, there may be areas of } \\
\text { ignorance where, in the presence of significant risk, the } \\
\text { precautionary principle may be appropriate. To reflect the } \\
\text { prevailing uncertainties results of appraisals need to be shown as } \\
\text { ranges rather than discrete numbers. Uncertainty and sensitivity } \\
\text { analysis can assist in highlighting the significance of ranges. }\end{array}$ & $\begin{array}{l}\text { Integral to most environmental decision-making tools. Issues of } \\
\text { blight and financial risk ensure this is problematic for most } \\
\text { contaminated sites. Emphasis on quality assurance and control } \\
\text { with respect to consulting advice, site investigation design and } \\
\text { practice and remedial monitoring. Often an over cautious } \\
\text { approach is adopted to overcome uncertainty. }\end{array}$ \\
\hline Using experts & $\begin{array}{l}\text { The appraisal community is now taking on board participatory } \\
\text { methods, combining scientists and non-experts. This raises } \\
\text { important challenges and methods of eliciting and sharing technical } \\
\text { information need to be developed and interrogated. }\end{array}$ & $\begin{array}{l}\text { Use of experts at public inquiry especially with respect to } \\
\text { remedial design and exposure assessments. Issues with respect to } \\
\text { human health effects and toxicological data are difficult and tend } \\
\text { to be addressed with reference to the deliberations of authoritative } \\
\text { expert panels and committees. Application of expert elicitation } \\
\text { techniques is common place in radioactive performance } \\
\text { assessment for elicitation of receptor characteristics and } \\
\text { representative 'futures'. }\end{array}$ \\
\hline $\begin{array}{l}\text { Deciding which } \\
\text { timescale is } \\
\text { appropriate }\end{array}$ & $\begin{array}{l}\text { For example, sustainable development requires a longer-term } \\
\text { perspective to be taken. There may be a need to undertake } \\
\text { 'scenario-building' in parallel with a particular appraisal technique. }\end{array}$ & $\begin{array}{l}\text { Issues of deciding when to intervene, for example, with respect to } \\
\text { plume transport towards a public water supply. Balancing times } \\
\text { required for detailed assessment alongside plume advancement. } \\
\text { Use of 'what-if' scenarios and futures to compare decisions. }\end{array}$ \\
\hline $\begin{array}{l}\text { Trading-off one } \\
\text { option against } \\
\text { another }\end{array}$ & $\begin{array}{l}\text { There are particular challenges regarding how to present } \\
\text { information on the trade-offs concerning risk management options. } \\
\text { This also raises issues surrounding the choice of decision factors, } \\
\text { the use of ranking, rating or scaling and, more controversially, } \\
\text { weightings. }\end{array}$ & $\begin{array}{l}\text { Challenges are particularly difficult where there is considerable } \\
\text { uncertainty in the component parts of the decision. Issue of } \\
\text { comparing quantitative and qualitative information is heightened. }\end{array}$ \\
\hline Post-project analysis & It is imperative that the process is evaluated and lessons learned. & Improved project design and decision-making processes. \\
\hline
\end{tabular}




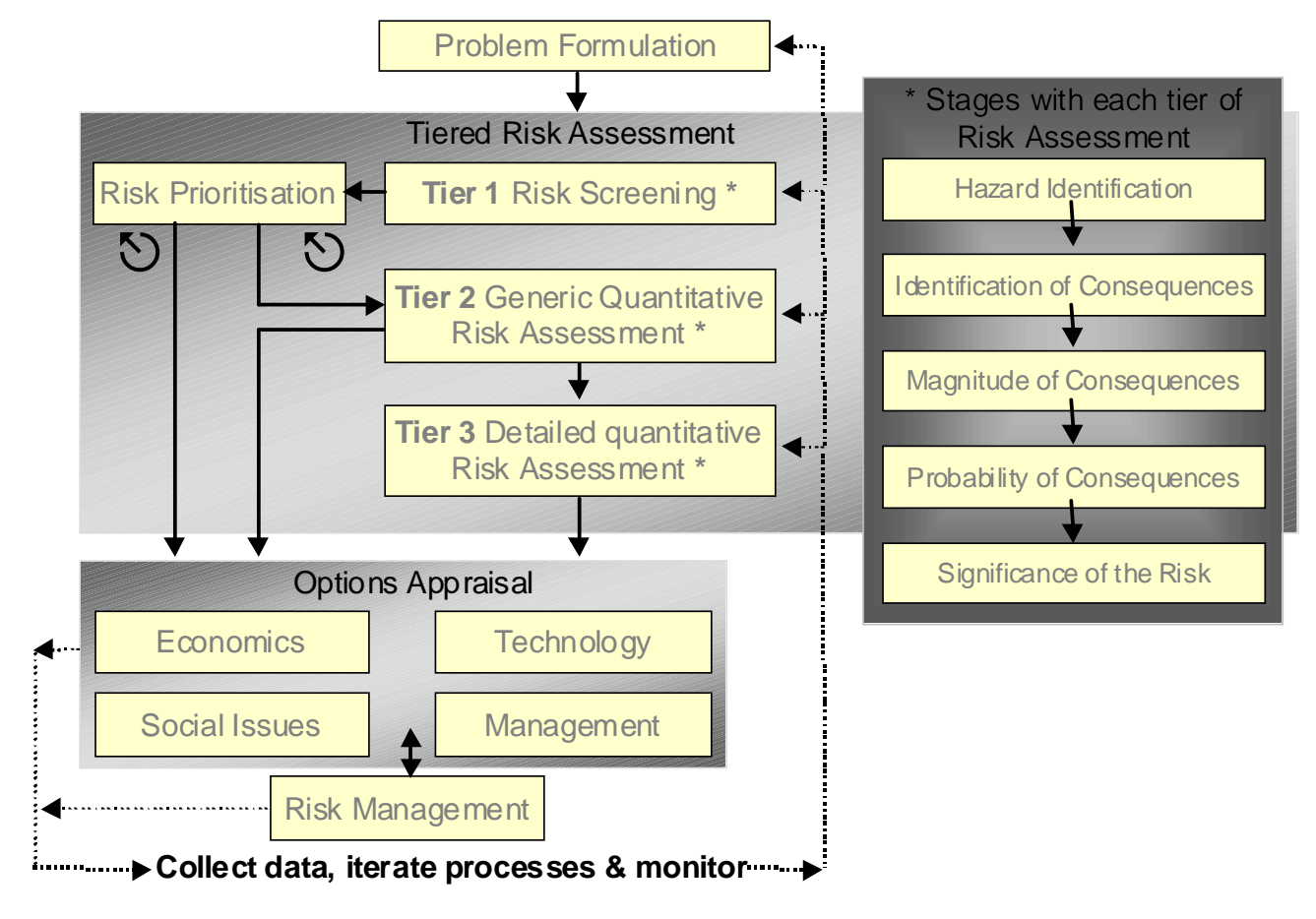

Fig. 2 Example framework for environmental risk management illustrating a tiered approach, iteration and early opportunities $(\circlearrowleft)$ to progress to risk management after rapid ( in this case, risk) appraisal.(after DETR, Environment Agency and IEH, 2000)

Decision-makers applying these frameworks find themselves responding to the expectations of a variety of stakeholders, many of whom have interests focused both on and beyond the technical analysis (Fischer, 1993; Homan et al., 2001; Petts et al., 2003a, b). The multiple terminologies of appraisal can be alienating to lay audiences and under these circumstances, while offering some clarity, structured risk management frameworks run a potential danger of implicitly assuming that the technical perspective is somehow pre-eminent (Petts et al., 2000) to other considerations. In many regulatory settings, some commentators have argued a potential disparity exists between a practical need to define regulatory procedures and the desire to engage the public in risk decisions where the 'technical' language of risk will compete with the colloquial language of the public (Petts et al., 2000). Being clear about expectations, therefore at the outset is critical if they are to be managed and met. 
2 It is clear from the above review and discussion that a growing literature exists on the

3 integration of tools for decision-making on land contamination. Clearly there are

4 potential traps for both practitioners and decision-makers on the capacity of these tools

5 to delivery improved decisions and assistance is required for the decision-making

6 community on how best to integrate the outputs of various techniques. However, we

7 can conclude that

8 (i) Decision-making frameworks can add value by making the routes to decisions transparent.

(ii) The current literature on environmental decision-making suggests that technically driven decisions made in isolation of other concerns is insufficient for many stakeholders.

(iii) Recent developments suggest a move forward to sustainable land management in the context of brownfield regeneration will necessitate the development and application of a broader and integrated portfolio of decision techniques.

(iv) We have yet to work through the implications of applying these tools alongside one another and develop the interfaces so they become commonplace for practitioners. 


\section{References}

Alker S, Joy V, Roberts P and Smith, N The Definition of brownfield. J Environ. Plan. and Manage. 2000; 43: 49-69.

ASTM. Risk based corrective action (RBCA) E1739-95 Standard guide for risk based corrective action applied at petroleum release sites, American Society for Testing and Materials, Philadelphia, 1995.

ASTM. Risk based corrective action (RBCA) E2081-00 Standard guide for risk based corrective action, American Society for Testing and Materials, Philadelphia, 2001.

Assmuth TW. Toward value-based environmental clean-up - a trans-scientific venture. presented at ConSoil '98, May 17-21, Edinburgh, 1998.

Bardos P, Nathanail CP and Weenk, A. Added environmental value: A tool to help understand the effects of remediation within the context of sustainable development. Summary of a workshop held at University of Nottingham, R\&D Project P5-23/01, Environment Agency, UK, 1999

Brookes A, Eales R, Fisher J, Foan, C and Twigger-Ross C. An approach to integrated appraisal: progress by the Environment Agency in England and Wales, J. Environ. Assess. Policy \& Manage. 2001; 3: 95-122

Cm 4345 A better quality of life: A strategy for sustainable development for the United Kingdom, The Stationery Office, London, 1999, 96pp.

CONCAWE European oil industry guideline for risk-based assessment of contaminated sites, CONCAWE Report 2/97, CONCAWE, Brussels, 1997, 41pp.

Defra. Draft soil strategy for England, Department for Environment, Food and Rural Affairs, London, 2001

Defra. Corporate risk management strategy, corporate strategy unit, Department for Environment Food and Rural Affairs, London, 2002, 29pp. available at URL http://www.Defra.gov.uk [accessed $8^{\text {th }}$ December 2002].

DETR. Review of technical guidance on environmental appraisal, a report by EFTEC, Department of the Environment, Transport and the Regions, London, 1998, 86pp

DETR. Circular 2/2000, Environmental Protection Act 1990 - Part IIA - Contaminated land, Department of Environment, Transport and the Regions, London, 2000, Annex I, paras. 6-7 
DETR, Environment Agency and Institute for Environment and Health. Guidelines for environmental risk assessment and management - revised departmental guidance, The Stationery Office, London, 2000, 88pp.

Earl N. and Kearney T. Methodology for comparison of human health risk assessment packages. In: Contaminated Soil 2000, Proceedings 7th TNO/FZK Conference on Contaminated Soils, Thomas Telford, Leipzig 18-22 September, 2000, Volume 2: 815-822.

Environment Agency. Assessing the wider value of remediating land contamination: a review. R\&D technical report P238, Environment Agency, Bristol, 2000a

Environment Agency. Costs and benefits associated with remediation of contaminated groundwater: A framework of assessment, $R \& D$ technical report P279, Environment Agency, Bristol, 2000b

Environment Agency. Model procedures for the management of land contamination consultation draft 2v2, CLR11, Environment Agency, Bristol, 2003, 107pp

ESRC Global Environmental Change Programme. Risky choices, soft disasters. Environmental decision-making under uncertainty, University of Sussex, Brighton, 2000, 25pp.

Ferguson C. Darmendrail D, Freir K, Jensen BK, Jensen, J, Kasamas H, Urzelai A and Vegter J. Risk assessment for contaminated sites in Europe. Volume 1. Scientific basis, LQM Press, Nottingham, 1998, 165pp.

Fischer F. The greening of risk assessment. In D. Smith (ed.) Business and the environment, PCP, London, 1993: 98-115.

Green Alliance. Steps into uncertainty: Handling risk and scientific uncertainty, Green Alliance and ESRC Global Environmental Change Programme, London, 2000, 6pp. available at www.green-alliance.org.uk/Publications

Homan J, Petts J, Pollard SJT and Twigger-Ross, C. In: K.Anderson (ed.) Proceedings of the 2nd VALDOR Symposium addressing transparency in risk assessment and decision-making, 10-14 June, Stockholm, Sweden, 2001: 398-406

House of Lords Select Committee on Science and Technology. 1999-2000 Session, 3rd Report. Science and society, HL Paper 38, The Stationery Office, London, 2000

ILGRA. Risk assessment and risk management: Improving policy and practice within government departments, HSE Books, Suffolk, 1998, 37pp. 
Martin I, Lowe M and Herbert, S. The use of cost-benefit analysis in selecting remedial options for contaminated land. In: Contaminated Soil '98, Thomas Telford, London, 1998: 1153-1154

Nijboer MN. REC: A decision support system for comparing soil remediation options based on risk reduction, environmental merit and costs. In: Contaminated Soil '98, Thomas Telford, London, 1998: 1173-1174.

Petts J. Municipal waste management: inequities and the role of deliberation. Risk Analysis, 2000; 20: 821-832

Petts J., Homan J. and Pollard S. Participatory risk assessment - involving lay audiences in environmental decisions on risk - literature review and stakeholder interviews. R\&D Report E2-043, Environment Agency, Bristol, 2003a, 96pp.

Petts J, Pollard, SJT, Gray AJ, Orr P, Homan J and Delbridge P. Involving lay audiences in environmental risk assessments. In: ConSoil 2003, Proceedings $8^{\text {th }}$ International FZK/TNO Conference on Contaminated land, 12-16 May 2003b, Ghent, Belgium, 2003, Theme D: 2969-2978

Pollard SJT Lythgo M. and Duarte-Davidson R. The extent of contaminated land problems and the scientific response. Issues in Environ. Sci. Technol., 2001a, 16: 1-19

Pollard SJT, Fisher J, Twigger-Ross C and Brookes A. In: NATO/CCMS, Evaluation of demonstrated and emerging technologies for the treatment and clean up of contaminated land and groundwater (Phase III), special session: decision support tools No.245, EPA 542-R-01-002, United States Environmental Protection Agency, Washington DC, 2001b: 105-116

Pollard SJT and Earl N. Risk management frameworks. In: Contaminated land management state of the art review (P Bardos and CP Nathanail (eds.), Thomas Telford, London, 2003, in press

Presidential / Congressional Commission on Risk Assessment and Risk Management (1997) Framework for environmental health risk management, Final Report, Volume 1, Washington DC, 1997

Puri G. and Gordon JE Soils and sustainability - A natural heritage perspective. In: Contaminated Soil '98, Thomas Telford, London, 1998: 1-5.

Renn, O. Risk communication: towards a rational discourse with the public. J. Haz. Mat 1992; 29: 465-519. 
RCEP. $21^{\text {st }}$ Report: Setting environmental standards, The Stationery Office, London, 1998, 232pp.

Sexton K, Marcus AA, Easter KW and Burkhardt TD (eds.) Better environmental decisions, Island Press, Washington DC, 1999, 475pp.

Stern PC and Fineberg HV. Understanding risk-informing decisions in a democratic society, National Research Council, National Academy Press, Washington DC, 1996, 249pp.

Urban Task Force. Towards an urban renaissance, E\&FN Spon, London, 1999

USEPA. Integrated decision-making in the $21^{\text {st }}$ century, Peer review draft, USEPA, Washington DC, 1999, available at: www.epa.gov/science1/irp/

USEPA. NATO/CCMS Evaluation of demonstrated and emerging technologies for the treatment and clean up of contaminated land and groundwater (Phase III), special session: decision support tools, No.245, USEPA, Washington DC, 2001

Van Der Vorst R, Grafé-Buckens A and Sheate WR (1999) A systemic framework for environmental decision-making, J. Environ. Assess. Policy \& Manage. 1999; 1: 126

Vegter JJ, Lowe J, Kasamas H (eds) Sustainable management of contaminated land: an overview, Austrian Federal Environment Agency, Wien, 2002, 128pp. 